\title{
Land and Capital Accumulation in Greek Agriculture by Region (1950-2010)
}

\author{
Theodore Papaelias ${ }^{1}$, Vasilis Panagou, Maria Rodosthenous
}

\begin{abstract}
:
After the liberation (1828) the land that belonged to the Turks became state-owned land. A large part of the state's revenue was covered by the rent. The distribution of national domain, as it was called; in the year 1871 solved the problem that arose by the farmer's discomfort against the state-landlord. A new important issue arose by the adaptation of Thessaly (1881), where the Turks when they were leaving, sold their land, often for very low price, to Greek capitalists. Thus, the manors appeared. This issue took tremendous dimensions at the beginning of the $20^{\text {th }}$ century with the villagers' riots at this region. After the Balkan Wars $(1912,1913)$ and World War I the annexation of Macedonia, Epirus and Thrace, where domains prevailed, inflated the problem. The entrance of the refugees after the Asia Minor disaster (1922) led the governments to extended land consolidation. In order to multiply the farming lands, at the decade of 1930, large productive works were carried out in northern Greece (drainage of lakes, ponds etc.). After World War II the program of landimprovement works was accelerated and as a result the number of irrigated lands was significantly increased and the cultivated land differed, while the plantations expanded very quickly. During 1950 to 80 through subsidy loans by the public Agriculture Bank, a modernization of agriculture was attempted (mechanization, improved seeds, pesticides etc) and restructuring of farming was partially achieved. The aim of this paper hereof is double: Firstly, it seeks to investigate, something which does not exist in Greek bibliography, what was the value of the land, in relevance to the capital accumulation, not only in the whole country, but also per prefecture and secondly, which was the contribution of the land improvement at the growth of the product. The data arose from long-term investigation of authors over the subject of framing the agriculture economy sizes and the method was based on the archives consultation.
\end{abstract}

Key Words: Capital Accumulation, Land Improvement, Agriculture Economy, Prefecture, Evaluation

JEL Classification: O13, R14

\footnotetext{
${ }^{1}$ Papaelias Theodore, TEI of Piraeus, department of Accounting, 250 Thivon \& Petrou Ralli, Egaleo,

Greece, thpap@teipir.gr
} 


\section{Introduction}

After the Revolution (1821-1828) the state kept the land of the Turks ${ }^{\mathrm{i}}$ under its possession. Zografos (1921 - 1924) estimates that the total land which was cultivated by Greeks and Turks before the revolution was less than $1 / 5$ of farmland. This means, that a big part of the land remained unexploited ${ }^{\mathrm{ii}}$.

The properties of the Turkish people which were removed were rented by the state to the peasants (landless or not) these were called "national domain". Until 1871, the major portion of these lands that were distributed to farmers was usurped. It has been estimated that they had contributed approximately $5-6 \%$ in state revenues ${ }^{\text {iii }}$ during the period 1840-1870.

The next reform took place in 1922, with the distribution of estates (manors). The annexation of Thessaly in Greece (1881) created the problem of large landholding. Turks fleeing sold their land to Greek capitalists. The annexation of Macedonia that followed (1912-13) and Eastern Macedonia and Thrace in 1919, where the estates dominated, created great topic (the agrarian question). The reform that was announced in 1917 was completed on the eve of the Second World War.

\section{Methodological Problems in the Presentation of Financial Data}

This essay is derived from longtime primary research and concerns findings of an extended period in which they occur substantial differences in the estimation method and information presentation. Before 1988, the system of national accounts, using the methodology of the immediate post-war experience of United Nations, provided a uniform way of recording and presenting data and, despite the periodic changes, they maintained a sort of continuity (were compared). The subsequent changes, especially after the use of ESA 95, were substantial. As the result frequently the figures are not comparable. Nevertheless, with micro "breakdowns", someone could compose, at least until 2000 in relative deviation from reality, a complete economic time series of data from 1950 to 2000 (and earlier). But the country's accession to the Eurozone interrupted the continuity and any approaches to the past remain problematic. After careful consideration, it was decided to evaluate the findings in U.S. dollars, perhaps not the best solution. The advantage of this decision is that for decades it constitutes the most recognizable currency in the world and easily can make internationally comparisons. However, such a similar deflator -naturallydistorts more or less the reality. 


\section{Public Fixed Capital of Land Reclamation}

The public net fixed capital of land reclamation during decades 1950, 60, 70, 80, 90 and 2000 is presented in millions US\$ - Table 1. Note that the fixed capital of reclamation (irrigation in the first level, flood control and drainage in the second) is the pivotal component of net fixed capital, both at country and regional level.

Of course, this evolution was not the same in all area during these fifty years. The indices showed that, on basis $1950=100$, the fastest change occurred in Attica, Western Macedonia and Western Greece ${ }^{i v}$.

Initially, because of the large projects undertaken in the period 1930-40 in the zone of Macedonia, the capital accumulation of land reclamation was the largest in this region. In 1950 in Central and Eastern Macedonia and Thrace it constituted 79.2\% of the total ${ }^{\mathrm{V}}$. Postwar, weight was given in Western Greece so that the fixed capital in 1950 stood at $1.6 \%$ and in 2000 approached $24 \%$ of the total.

\section{Private Fixed Capital: Land Improvements}

This capital showed strong fluctuations in the reported period. During the first thirty years it increased rapidly (Table 2).

Subsequently, it is presented decreased (1980-1990) and then seemed to recover slightly. This capital related to expenditures on land improvements and irrigation, where farmers have gone in order to improve their own productivity on their land. Often they were "obliged" to do it, because of consolidations (redistributions of land) that were made, as a result of public works.

Previously, especially during 1830-1930 (Evelpides, 1957), these costs were extremely important, but they were not being valued, and they constituted the socalled invisible (unrecorded) investments ${ }^{\mathrm{vi}}$.

On the basis on $1950=100$, the largest change occurred in Western Greece and then in Athens and Crete ${ }^{v i i}$. In many areas public investment (involving mainly irrigation) had as result the "attraction" of private, so as the farmers to receive benefits from public works.

If somebody investigates the structure of this capital through the time, he will see (Papailias, 2012) that in 2000, in Central Macedonia (as in 1950) the largest land improvements were implemented by farmers. Equally significant investments are recorded in Western Greece ${ }^{\text {viii }}$. 


\section{The Value of Land ("Land Capital")}

The findings regarding the value of land first appeared in 2003 (Papailias, Panagou 2003) and counted inventory. From the total cultivated land the plantations were removed, as these were the vegetable section (plants); thus, leaving the value of the arable and horticultural. Also, the greenhouses units' land was not included, because they are assessed in the private fixed capital.

The value of land was approached during the years 1950, 1955, 1960, 1970, 1980, 1988, 1990 and 2000.

Table 3 shows the valuation of the land at the region level.

The structure reveals severe alterations. After 1990, the land becomes object of speculation. The largest share is detected in Central Macedonia (23.2\% in 1950, $26.6 \%$ in 2000), Thessaly ( $15.6 \%$ at the beginning and $18.7 \%$ at the end of the period) and Central Greece (11.9\% in 1950, $10.5 \%$ in 2000) ${ }^{\mathrm{ix}}$.

The fastest evolution occurred in Attica (9.7 times), Crete (1.8 times), and South Aegean (1.7 times). In several regions there was a serious decline (in the Peloponnese value shrank to $60 \%$ of that of 1950 , while in Western Macedonia with indices $1950=100$ in 2000 fell to 66). But the greatest reduction was recorded in the Epirus region (the indices slipped to 52$)^{\mathrm{x}}$.

So, the value of the land tends to decline or to remain stable. We notice the exception of Attica, the islands of the South Aegean and Crete region, where both of them (rural and urban lands' values) verge to equalize, due to tourism development, after 1980 .

\section{The "Land Capital" in the Assets Holdings}

Tables 4, 5, 6, 7, 8 and 9 reflect the participation of the value of land in the Greek assets holdings en block during years 1950-2000 respectively.

In 1950 - Table 4- the value of land consisted in 52\% of total assets, while fixed capital from public and private investment was just 6,3\%. The value of plant ("Plant capital") was the next strong component (31\%). On the contrary the current (basically short-term loans from the Agricultural Bank) was $2 \%$.

In 1960 -Table 5- the share of land seems to shrink, touching to $46 \%$ compared to $30 \%$ of plant and $11.7 \%$ of fixed capital (public and private accumulation).

In 1970 -Table 6- the share of the land was decline quite significantly (31.7\%) despite the increase of cultivated land, while it was significantly over the plant 
capital (33.8\%), which became the largest component of assets, and fixed (22.5\%). The period 1950-1980 was one which the double developmental squeeze was applied. The result was to leave the countryside, between 1955 and 1971, 1.4 million farmers for the abroad or the cities with consequence the considerable fall of the value of the land

The income decreased extremely, consequently, the dictatorship in 1968 decided to delete debts 100 thousand drachmas per farm. The capital accumulation was achieved mainly because of public activity and loans (long-term) that were granted by ATE.

The same trend prevailed, as said, and in 1980 - Table 7. The value of land was reduced to $28.6 \%$, while the accumulation of capital from public and private investment amounted to $33.3 \%$ and it was the main component of the total assets of the agricultural holdings. The value of plants as percentage of the total assets was decreased.

Table 8 shows the evolution of the assets of all the holdings, after a decade's participation in E.E. (Greece's accession 01.01.1981). The percentage of the value of land appears to incline slightly, like the plants, whose share increases faster. Instead, the public (mainly) and, secondarily, private investment declined in pace, resulting in decline of participation of capital accumulation in the assets of the country.

In 2000 - Table 9 - the fixed capital has lost all its momentum (public investments cover slightly the amount of depreciation), while private is also low. The plants rose rapidly (mainly, it refers to olive groves). The production of the olive in Greece is enormous, so the country is now close to Italy with potential to become the second largest producer of olive-oil after Spain worldwide.

The value of the land rose significantly. A part of the land in many regions of the country like Crete, South, North Aegean Island, Attica etc. becomes marketable due to urban and tourist development. Particularly, in many islands, the theory of George (1879) seems to find vindication.

\section{Evaluation of Land Capital in Agricultural Production}

Table 10 presents the basic components of the agricultural sector: area of cultivated land, capital accumulation, rural output and employment in selected years during 1911-2000. It is presumed that in 1911, 850.000 farmers with capital 31.2 billion drachmas (at constant prices 1970) cultivated 9.9 million $\mathrm{m}^{\wedge} 2$ and created income of 10 billion drachmas (at constant prices of 1970). 
In 1990, after one remarkable modernization (the mechanization of Greek agriculture during the era 1950-1980 was one of the fastest in the world), the following situation appeared: 895 thousands of farmers (some more of those during 1911) in 35,1 million $\mathrm{m}^{\wedge} 2$ compared with 9.9 in 1911 produced 56.9 billion drachmas product in 1970 prices.

That means that, the same number of people having capital 7 times bigger and 3.5 times more land created income 6 times larger. Of course, this approach does not take into account the improvement of productivity of the soil ${ }^{\mathrm{xi}}$.

This partly reflected in the value of land reclamation ${ }^{\text {xii. }}$.

According to Evelpides $(1950,1957)$, the agricultural holdings remained short in the immediate post-war years (1949-1953). As demonstrated (Papailias 2012), they were deficient, grosso modo, in the total country during all the postwar space. The economic surplus was transferred to the urban sector. As proposed (Andreades 1919, Sakellaropoulos 1991, Tsoukalas 1983, Kayser 1964), throughout this period the creation of stable social and political structures capable of "prying" the surplus of the villagers, was impossible.

It seems that the increase land's productivity, such as dimly apparent from Table 10, was a critical factor in the growth of product. It should not escape our attention that the data, which show the rural product, hide a part of the reality. Due to the double developmental squeeze, the prices of agricultural commodities were controlled, during this period, in relation to those of the urban sector (internal terms of trade were obviously against farmers). Consequently, the total increase of the value hides the largest growth of the volume production. It is estimated ${ }^{\mathrm{xiii}}$ that in the era 19501980, while the value tripled -Table 10 - the volume multiplied more than five times. It's explained, mainly, by the improvement of land's productivity (it was the major component).

\section{Conclusion}

Throughout the period 1828-2012, the peasant movement was not developed in Greece. The prevalence of individual use of the land (Karavidas 1931), although damaging to the medium farmer, has enabled the state to divert financial resources from agriculture to benefit the urban sector (crafts, industry, trade and services in general). The structure of the rural sector -a classic case of what is called in Political Economy perfect competition - has not allowed the peasants to exploit to their benefit the increased productivity of the land (Papailias 2012). The main victims of any growth achieved in Greece were the farmers, at least in the period 1828-1980. Later, the EU subsidies will increase the income of rural people, but in the other hand have undermining the prospects in long term period to progress. The improvements to the land, after the country's accession to the EU, declined. The 
crops remained about the same, the capital accumulation almost tends to stop, as consequence the end of subsidies that expect after 2013, with result to create an acute question of survival in the midst holdings.

Table 1

Public Fixed Capital of Land Reclamation (1950-2000)

In U.S. Dollars

Million

\begin{tabular}{|c|c|c|c|c|c|c|}
\hline Regions & 1950 & 1960 & 1970 & 1980 & 1990 & 2000 \\
\hline Attica & 0,1 & 0,0 & 4,1 & 11,5 & 50,7 & 47,2 \\
\hline Central Greece- Euboea & 14,5 & 13,0 & 26,9 & 106,5 & 173,5 & 156,6 \\
\hline Western Greece & 4,5 & 15,4 & 204,0 & 1104,3 & 1350,7 & 1151,1 \\
\hline Peloponnese & 8,9 & 9,1 & 32,6 & 252,8 & 230,3 & 254,4 \\
\hline Ionian Island & 0,5 & 0,8 & 1,2 & 3,9 & 7,6 & 8,2 \\
\hline Epirus & 11,5 & 16,6 & 49,8 & 175,7 & 285,8 & 295,4 \\
\hline Thessaly & 17,7 & 21,2 & 62,6 & 355,9 & 475,3 & 397,0 \\
\hline West. Macedonia & 0,1 & 1,0 & 7,8 & 42,9 & 85,2 & 94,0 \\
\hline East. Macedonia-Thrace & 39,4 & 44,3 & 118,5 & 569,6 & 937,3 & 830,7 \\
\hline Central Macedonia & 188,3 & 174,3 & 320,4 & 1180,8 & 1670,9 & 1363,1 \\
\hline South Aegean Island & 0,0 & 0,1 & 0,8 & 3,4 & 14,0 & 13,0 \\
\hline North Aegean Island & 0,0 & 0,4 & 1,6 & 7,8 & 11,8 & 11,6 \\
\hline Crete & 2,1 & 2,2 & 9,5 & 81,6 & 256,7 & 196,1 \\
\hline Total & 287,5 & 298,4 & 839,7 & 3896,9 & 5550,0 & 4818,5 \\
\hline
\end{tabular}

Source: Papaelias-Panagou (2003) 
Table 2

Private Fixed Capital: Land Improvements (1950-2000)

In U.S.Dollars

Million

\begin{tabular}{|c|c|c|c|c|c|c|}
\hline Regions & 1950 & 1960 & 1970 & 1980 & 1990 & 2000 \\
\hline Attica & 1,2 & 2,2 & 6,0 & 44,3 & 31,6 & 49,7 \\
\hline Central Greece- Euboea & 6,9 & 14,7 & 30,8 & 87,0 & 64,5 & 108,2 \\
\hline West. Greece & 7,2 & 36,4 & 94,4 & 458,5 & 426,5 & 467,4 \\
\hline Peloponnese & 8,1 & 15,6 & 24,0 & 88,8 & 74,1 & 93,2 \\
\hline Ionian Island & 2,7 & 4,0 & 7,1 & 24,1 & 16,8 & 19,6 \\
\hline Epirus & 4,6 & 7,0 & 18,4 & 89,1 & 80,7 & 76,3 \\
\hline Thessaly & 7,3 & 11,6 & 34,6 & 150,9 & 146,0 & 162,6 \\
\hline West. Macedonia & 3,0 & 2,4 & 5,3 & 21,2 & 32,6 & 45,9 \\
\hline East. Macedonia-Thrace & 7,1 & 16,0 & 40,9 & 157,9 & 114,6 & 113,1 \\
\hline Central Macedonia & 35,0 & 68,1 & 138,8 & 534,0 & 472,6 & 497,6 \\
\hline South Aegean Island & 2,0 & 2,4 & 4,7 & 19,5 & 20,7 & 29,9 \\
\hline North Aegean Island & 2,5 & 3,3 & 6,7 & 19,3 & 10,3 & 12,3 \\
\hline Crete & 5,7 & 11,5 & 24,3 & 91,4 & 98,1 & 137,1 \\
\hline Total & 93,4 & 195,0 & 436,1 & $1.785,9$ & $1.589,2$ & $1.812,9$ \\
\hline
\end{tabular}

Source: Papaelias-Panagou (2003) 


\section{Table 3}

\section{"Land capital" per regions}

In U.S. Dollars

Million

\begin{tabular}{|l|r|r|r|r|r|r|}
\hline \multicolumn{1}{|c|}{ Regions } & \multicolumn{1}{|c|}{1950} & \multicolumn{1}{c|}{1960} & \multicolumn{1}{c|}{1970} & \multicolumn{1}{c|}{1980} & \multicolumn{1}{c|}{2000} & \\
\hline Attica & 40,2 & 27,4 & 33,6 & 216,6 & 826,6 & $2.352,3$ \\
\hline Central Greece- Euboea & 461,3 & 291,6 & 323,2 & $1.012,2$ & $1.348,3$ & $3.300,6$ \\
\hline West. Greece & 327,3 & 211,4 & 224,7 & 899,3 & $1.208,9$ & $2.918,2$ \\
\hline Peloponnese & 384,4 & 240,8 & 209,7 & 566,6 & 568,9 & $1.397,2$ \\
\hline Ionian Island & 41,0 & 26,8 & 25,2 & 61,4 & 91,7 & 311,8 \\
\hline Epirus & 152,7 & 89,3 & 82,3 & 222,4 & 238,1 & 475,8 \\
\hline Thessaly & 288,5 & 370,1 & 477,1 & $1.640,9$ & $2.730,5$ & $5.853,2$ \\
\hline West. Macedonia & 254,9 & 178,9 & 180,6 & 326,4 & 528,1 & $1.012,6$ \\
\hline East. Macedonia-Thrace & 452,2 & 321,4 & 357,1 & $1.043,4$ & $1.157,8$ & $2.885,4$ \\
\hline Central Macedonia & 900,5 & 570,8 & 718,6 & $2.489,5$ & $3.382,8$ & $8.335,5$ \\
\hline South Aegean Island & 79,0 & 51,0 & 45,9 & 148,8 & 275,0 & 757,8 \\
\hline North Aegean Island & 69,1 & 44,5 & 35,9 & 117,5 & 141,8 & 431,0 \\
\hline Crete & 119,4 & 87,9 & 96,6 & 257,7 & 778,2 & $1.305,1$ \\
\hline Total & $3.570,5$ & $2.512,1$ & $2.810,5$ & $9.002,8$ & $13.276,5$ & $31.336,4$ \\
\hline Source Papan & & & & & & \\
\hline
\end{tabular}

Source: Papaelias-Panagou (2003) 
Table 4

Structure of Assets Total Country 1950

\begin{tabular}{|l|r|r|}
\hline \multicolumn{1}{|c|}{ Assets } & \multicolumn{1}{c|}{ In U.S. Dollars } & \multicolumn{2}{c|}{$\%$} \\
\hline Total fixed capital & 433,0 & 6,29 \\
\hline Plants & $2.128,0$ & 30,93 \\
\hline Livestock & 613,0 & 8,91 \\
\hline Land & $3.571,0$ & 51,90 \\
\hline Current & 136,0 & 1,98 \\
\hline Total & $6.880,0$ & 100,00 \\
\hline
\end{tabular}

Source: Papaelias-Panagou (2003)

Table 5

Structure of Assets Total Country 1960

\begin{tabular}{|l|r|r|}
\hline \multicolumn{1}{|c|}{ Assets } & In U.S. Dollars & \multicolumn{1}{c|}{$\%$} \\
\hline Total fixed capital & 641,0 & 11,71 \\
\hline Plants & $1.633,0$ & 29,83 \\
\hline Livestock & 461,0 & 8,42 \\
\hline Land & $2.512,0$ & 45,88 \\
\hline Current & 228,0 & 4,16 \\
\hline Total & $5.475,0$ & 100,00 \\
\hline
\end{tabular}

Source: Papaelias-Panagou (2003) 
Table 6

Structure of Assets Total Country 1970

\begin{tabular}{|l|r|r|}
\hline \multicolumn{1}{|c|}{ Assets } & In U.S. Dollars & \multicolumn{2}{c|}{} \\
\hline Total fixed capital & 1992,00 & 22,49 \\
\hline Plants & 2994,00 & 33,80 \\
\hline Livestock & 551,00 & 6,22 \\
\hline Land & 2811,00 & 31,73 \\
\hline Current & 511,00 & 5,77 \\
\hline Total & $8.859,00$ & 100,00 \\
\hline
\end{tabular}

Source: Papaelias-Panagou (2003)

Table 7

Structure of Assets Total Country 1980

\begin{tabular}{|l|r|r|}
\hline \multicolumn{1}{|c|}{ Assets } & \multicolumn{1}{c|}{ In U.S. Dollars } & \multicolumn{1}{c|}{$\%$} \\
\hline Total fixed capital & 10.493 & 33,34 \\
\hline Plants & 7.603 & 24,15 \\
\hline Livestock & 2.567 & 8,16 \\
\hline Land & 9.003 & 28,60 \\
\hline Current & 1.810 & 5,75 \\
\hline Total & $31.476,00$ & 100,00 \\
\hline
\end{tabular}

Source: Papaelias-Panagou (2003) 
Table 8

Structure of Assets Total Country 1990

\begin{tabular}{|l|r|r|}
\hline \multicolumn{1}{|c|}{ Assets } & In U.S. Dollars & $\%$ \\
\hline Total fixed capital & $13.353,00$ & 29,88 \\
\hline Plants & $12.302,00$ & 27,52 \\
\hline Livestock & $3.532,00$ & 7,90 \\
\hline Land & $13.276,00$ & 29,70 \\
\hline Current & $2.232,00$ & 4,99 \\
\hline Total & $44.695,00$ & 100,00 \\
\hline
\end{tabular}

Source: Papaelias-Panagou (2003)

Table 9

Structure of Assets Total Country 2000

\begin{tabular}{|l|r|r|}
\hline \multicolumn{1}{|c|}{ Assets } & In U.S. Dollars & \multicolumn{1}{c|}{$\%$} \\
\hline Total fixed capital & 14.237 & 16,26 \\
\hline Plants & 35.353 & 40,38 \\
\hline Livestock & 3.515 & 4,01 \\
\hline Land & 31.336 & 35,79 \\
\hline Current & 3.116 & 3,56 \\
\hline Total & $87.557,00$ & 100,00 \\
\hline
\end{tabular}

Source: Papaelias-Panagou (2003) 


\section{Table10}

Land, capital, employment, product (1911-2000)

\begin{tabular}{|c|c|c|c|c|}
\hline Year & Land & Capital & Product & Employment \\
& stremmas.) & $1970)$ & prices 1970) & ('000 person) \\
\hline 1911 & 9.913 & 31.218 & 9.985 & 850 \\
\hline 1940 & 27.380 & 85.027 & 17.013 & 1.949 \\
\hline 1950 & 27.253 & 81.760 & 20.683 & 1.892 \\
\hline 1960 & 35.630 & 124.161 & 29.863 & 2.039 \\
\hline 1970 & 34.463 & 168.452 & 47.058 & 1.658 \\
\hline 1980 & 34.917 & 214.377 & 60.499 & 1.281 \\
\hline 1990 & 35.100 & 220.463 & 56.900 & 895 \\
\hline 2000 & 34.900 & 238.200 & 61.300 & 680 \\
\hline
\end{tabular}

Source: Years 1911-1990 Papailias (1992), year 2000 Papailias-Panagou (2003 
${ }^{\mathrm{i}}$ Residents in 1821:

\begin{tabular}{|l|l|l|}
\hline Regions & Greeks & Turks \\
\hline Peloponnese & 458.000 & 47.750 \\
\hline Central Greece \& Euboea & 247.850 & 20.865 \\
\hline
\end{tabular}

Source: Zografos (1921) pp. 461-2

ii

\begin{tabular}{|l|l|l|l|l|l|}
\hline \multirow{2}{*}{ Regions } & Greeks & Turks & Total & $\begin{array}{l}\text { Total } \\
\text { areas }\end{array}$ & $\begin{array}{l}\% \\
\text { cultivated } \\
\text { areas }\end{array}$ \\
\cline { 2 - 6 } & \multicolumn{2}{|l|}{ In stremmas } & \multicolumn{3}{|l|}{} \\
\hline Peloponnese & 1.500 .000 & 3.000 .000 & 4.500 .000 & 22.200 .000 & 20,45 \\
\hline \begin{tabular}{l} 
Central $\begin{array}{l}\text { Greece } \\
\text { Euboea }\end{array}$ \\
\hline
\end{tabular} & 2.629 .100 & 1.480 .130 & 4.109 .230 & 24.078 .000 & 17,06 \\
\hline
\end{tabular}

Source: Zografos (1921) p. 461

iii According to Soutsos the number of growers on national domain: 1 . ranged between $1 / 2$ and $1 / 3$ of the total rural population, 2. Paid the tithe (varying from $8 \%$ to $30 \%$ ) and the right of usufruct $(15 \%)$ of the gross product, 3. The national domain were a total of 6 million stremmas (1/3 of arable land), 4. The right to property brought to the public about 2 million drachmas annually. Soutsos (1868). See also Sideres (1933), Vergopoulos (1975), Andreades (1939)

${ }^{\text {iv }}$ Public Fixed Capital of Land Reclamation (1950-2000) Indices $(1950=100)$

\begin{tabular}{|l|l|l|l|l|l|l|}
\hline Regions & 1950 & 1960 & 1970 & 1980 & 1990 & 2000 \\
\hline Attica & 100 & 93 & 6.906 & 6.173 & 19.636 & 21.832 \\
\hline Central Greece-Euboea & 100 & 90 & 125 & 159 & 187 & 201 \\
\hline West. Greece & 100 & 347 & 3.088 & 5.338 & 4.716 & 4.796 \\
\hline Peloponnese & 100 & 103 & 248 & 615 & 405 & 533 \\
\hline Ionian Island & 100 & 165 & 162 & 169 & 236 & 302 \\
\hline Epirus & 100 & 145 & 293 & 330 & 388 & 478 \\
\hline Thessaly & 100 & 120 & 239 & 434 & 418 & 417 \\
\hline West Macedonia & 100 & 868 & 4.715 & 8.314 & 11.932 & 15.690 \\
\hline $\begin{array}{l}\text { East. Macedonia- } \\
\text { Thrace }\end{array}$ & 100 & 113 & 203 & 312 & 371 & 392 \\
\hline Central Macedonia & 100 & 93 & 115 & 135 & 138 & 135 \\
\hline South Aegean Island & & & & & & \\
\hline North Aegean Island & & & & & & \\
\hline Crete & 100 & 102 & 301 & 826 & 1.876 & 1.710 \\
\hline Total & 100 & 104 & 197 & 293 & 301 & 312 \\
\hline
\end{tabular}


${ }^{\mathrm{v}}$ Structure of Public Fixed Capital of Land Reclamation (1950-2000) \%

\begin{tabular}{|l|l|l|l|l|l|l|}
\hline Regions & 1950 & 1960 & 1970 & 1980 & 1990 & 2000 \\
\hline Attica & 0,01 & 0,01 & 0,49 & 0,30 & 0,91 & 0,98 \\
\hline Central Greece- Euboea & 5,04 & 4,37 & 3,20 & 2,73 & 3,13 & 3,25 \\
\hline Western Greece & 1,55 & 5,16 & $\begin{array}{l}24,3 \\
0\end{array}$ & 28,34 & 24,34 & 23,89 \\
\hline Peloponnese & 3,09 & 3,04 & 3,89 & 6,49 & 4,15 & 5,28 \\
\hline Ionian Island & 0,18 & 0,28 & 0,14 & 0,10 & 0,14 & 0,17 \\
\hline Epirus & 3,99 & 5,56 & 5,94 & 4,51 & 5,15 & 6,13 \\
\hline Thessaly Macedonia- & 13,71 & 14,86 & 14,1 & 14,62 & 16,89 & 17,24 \\
\hline West. Macedonia & 6,16 & 7,09 & 7,45 & 9,13 & 8,56 & 8,24 \\
\hline $\begin{array}{l}\text { East. } \\
\text { Thrace }\end{array}$ & 6,04 & 0,32 & 0,93 & 1,10 & 1,54 & 1,95 \\
\hline Central Macedonia & 65,49 & 58,42 & 38,1 & 30,30 & 30,11 & 28,29 \\
& 0,00 & 0,05 & 0,09 & 0,09 & 0,25 & 0,27 \\
\hline South Aegean Island & 0,00 & 0,12 & 0,18 & 0,20 & 0,21 & 0,24 \\
\hline North Aegean Island & 0,74 & 0,72 & 1,13 & 2,09 & 4,62 & 4,07 \\
\hline Crete & 100,00 & 100,00 & 100, & 100,0 & 100,0 & 100,0 \\
\hline Total & & & 00 & 0 & 0 & 0 \\
\hline
\end{tabular}

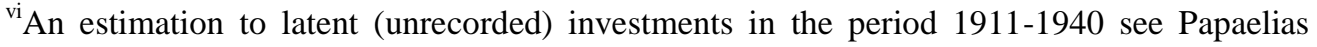
(1992)

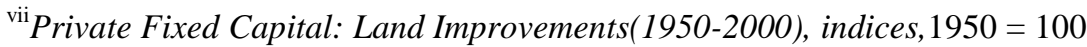

\begin{tabular}{|l|l|l|l|l|l|l|}
\hline Regions & 1950 & 1960 & 1970 & 1980 & 1990 & 2000 \\
\hline Attica & 100 & 187 & 343 & 804 & 502 & 694 \\
\hline Central Greece- Euboea & 100 & 212 & 299 & 270 & 175 & 259 \\
\hline West. Greece & 100 & 507 & 885 & 1.373 & 1.116 & 1.079 \\
\hline Peloponnese & 100 & 193 & 199 & 236 & 172 & 191 \\
\hline Ionian Island & 100 & 145 & 175 & 189 & 115 & 118 \\
\hline Epirus & 100 & 152 & 269 & 416 & 329 & 274 \\
\hline Thessaly & 100 & 158 & 318 & 442 & 374 & 367 \\
\hline West. Macedonia & 100 & 82 & 120 & 155 & 208 & 258 \\
\hline $\begin{array}{l}\text { East. Macedonia- } \\
\text { Thrace }\end{array}$ & 100 & 225 & 387 & 477 & 303 & 264 \\
\hline Central Macedonia & 100 & 196 & 268 & 330 & 255 & 237 \\
\hline South Aegean Island & 100 & 123 & 161 & 213 & 198 & 252 \\
\hline North Aegean Island & 100 & 135 & 184 & 168 & 79 & 83 \\
\hline Crete & 100 & 204 & 289 & 347 & 326 & 401 \\
\hline Total & 100 & 210 & 315 & 413 & 321 & 323 \\
\hline
\end{tabular}


International Journal of Economics \& Business Administration, I(1)2014

T. Papaelias - V. Panagou - M. Rodosthenous

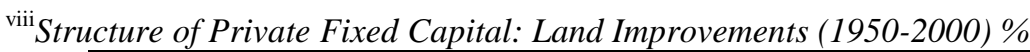

\begin{tabular}{|l|l|l|l|l|l|l|}
\hline Regions & 1950 & 1960 & 1970 & 1980 & 1990 & 2000 \\
\hline Attica & 1,27 & 1,13 & 1,39 & 2,48 & 1,99 & 2,74 \\
\hline Central Greece- Euboea & 7,45 & 7,52 & 7,07 & 4,87 & 4,06 & 5,97 \\
\hline West. Greece & 7,71 & 18,64 & 21,65 & 25,67 & 26,84 & 25,78 \\
\hline Peloponnese & 8,70 & 7,98 & 5,49 & 4,97 & 4,66 & 5,14 \\
\hline Ionian Island & 2,96 & 2,04 & 1,64 & 1,35 & 1,06 & 1,08 \\
\hline Epirus & 4,95 & 3,58 & 4,22 & 4,99 & 5,08 & 4,21 \\
\hline Thessaly & 7,88 & 5,93 & 7,94 & 8,45 & 9,19 & 8,97 \\
\hline West. Macedonia & 3,17 & 1,24 & 1,21 & 1,19 & 2,05 & 2,53 \\
\hline $\begin{array}{l}\text { East. Macedonia- } \\
\text { Thrace }\end{array}$ & 7,64 & 8,18 & 9,37 & 8,84 & 7,21 & 6,24 \\
\hline Central Macedonia & 37,43 & 34,94 & 31,84 & 29,90 & 29,74 & 27,45 \\
\hline South Aegean Island & 2,11 & 1,24 & 1,08 & 1,09 & 1,30 & 1,65 \\
\hline North Aegean Island & 2,64 & 1,69 & 1,54 & 1,08 & 0,65 & 0,68 \\
\hline Crete & 6,08 & 5,89 & 5,56 & 5,12 & 6,17 & 7,56 \\
\hline Total & 100,00 & 100,00 & 100,00 & 100,00 & 100,00 & 100,00 \\
\hline
\end{tabular}

${ }^{\mathrm{ix}}$ Structure of Value of Land (1950-2000) \%

\begin{tabular}{|l|l|l|l|l|l|l|}
\hline Regions & 1950 & 1960 & 1970 & 1980 & 1990 & 2000 \\
\hline Attica & 1,04 & 1,09 & 1,20 & 2,41 & 6,23 & 7,51 \\
\hline Central Greece- Euboea & 11,88 & 11,61 & 11,50 & 11,24 & 10,16 & 10,53 \\
\hline West. Greece & 8,43 & 8,42 & 8,00 & 9,99 & 9,11 & 9,31 \\
\hline Peloponnese & 9,90 & 9,59 & 7,46 & 6,29 & 4,28 & 4,46 \\
\hline Ionian Island & 1,06 & 1,07 & 0,90 & 0,68 & 0,69 & 1,00 \\
\hline Epirus & 3,93 & 3,55 & 2,93 & 2,47 & 1,79 & 1,52 \\
\hline Thessaly & 15,59 & 14,73 & 16,97 & 18,23 & 20,57 & 18,68 \\
\hline West. Macedonia & 6,56 & 7,12 & 6,43 & 3,63 & 3,98 & 3,23 \\
\hline $\begin{array}{l}\text { East. Macedonia- } \\
\text { Thrace }\end{array}$ & 11,65 & 12,79 & 12,71 & 11,59 & 8,72 & 9,21 \\
\hline Central Macedonia & 23,20 & 22,72 & 25,57 & 27,65 & 25,48 & 26,60 \\
\hline South Aegean Island & 1,91 & 2,03 & 1,63 & 1,65 & 2,07 & 2,42 \\
\hline North Aegean Island & 1,78 & 1,77 & 1,28 & 1,30 & 1,07 & 1,38 \\
\hline Crete & 3,08 & 3,50 & 3,44 & 2,86 & 5,86 & 4,16 \\
\hline Total & 100,00 & 100,00 & 100,00 & 100,00 & 100,00 & 100,00 \\
\hline
\end{tabular}


${ }^{\mathrm{x}}$ Value of Land (1950-2000) Indices $1950=100$

\begin{tabular}{|l|l|l|l|l|l|l|}
\hline Regions & 1950 & 1960 & 1970 & 1980 & 1990 & 2000 \\
\hline Attica & 100 & 68 & 56 & 116 & 388 & 973 \\
\hline Central Greece- Euboea & 100 & 64 & 47 & 47 & 55 & 119 \\
\hline West. Greece & 100 & 65 & 46 & 59 & 70 & 148 \\
\hline Peloponnese & 100 & 63 & 37 & 32 & 28 & 60 \\
\hline Ionian Island & 100 & 66 & 41 & 32 & 42 & 126 \\
\hline Epirus & 100 & 59 & 36 & 31 & 29 & 52 \\
\hline Thessaly & 100 & 62 & 53 & 59 & 85 & 161 \\
\hline West. Macedonia & 100 & 71 & 48 & 28 & 39 & 66 \\
\hline $\begin{array}{l}\text { East. Macedonia- } \\
\text { Thrace }\end{array}$ & 100 & 71 & 53 & 50 & 48 & 106 \\
\hline Central Macedonia & 100 & 64 & 54 & 60 & 71 & 154 \\
\hline South Aegean Island & 100 & 69 & 42 & 43 & 70 & 170 \\
\hline North Aegean Island & 100 & 65 & 35 & 37 & 39 & 104 \\
\hline Crete & 100 & 74 & 55 & 47 & 123 & 182 \\
\hline Total & 100 & 65 & 49 & 50 & 64 & 134 \\
\hline
\end{tabular}

${ }^{\mathrm{xi}}$ Irrigated land (in thousand stremmas):

\begin{tabular}{|l|l|}
\hline 1929 & 1.780 \\
\hline 1940 & 2.700 \\
\hline 1950 & 2.300 \\
\hline 1960 & 4.100 \\
\hline 1970 & 7.200 \\
\hline 1980 & 9.606 \\
\hline 1990 & 13.000 \\
\hline
\end{tabular}

Source: Bank of Greece (1978) and Papaelias (1992)

${ }^{x i i}$ In a next article production functions are estimated per thirty years: 1911-1940, 1950-1980 and 1980-2010 with the aim of measuring the increase in revenue due to technological change

xiii The econometric approach will be demonstrated in a next article with data as above 


\section{References}

Andreades, A. (1919), "Les Progrès Economique de la Grèce"

Bank of Greece (1978), "The First 50 years of the Bank of Greece", Ministry of Agriculture, "Reports various years", Athens

Evelpides, C. (1950), "Economic and Social History of Greece", Athens

Evelpides, C. (1957), "Agricultural Economics", Athens

George, H. (1879), "Progress and Poverty"

Karavidas, K. (1931), "Agrotika", Athens,

Kayser, B. (1964), "Géographie Humaine de la Grèce"

Mouzelis, N. (1978), "Modern Greece: Facts of Underdevelopment”, Macmillan, London

Papaelias, T. (1992), "Investments, Capital \& Productivity in the Agricultural Sector 19111990", ATE, Athens

Papaelias, T. and Panagou, V. (2003), "Balance Sheets in the Greek Agricultural per Regions and Country $(1950,60,70,80,90,2000)$ ", Athens

Papailias, M. (2012), "Financial and Accounting Summary of the Greek Agricultural Sector 1950-2000: Central Greece", EBEEC, Bulgaria, Sofia.

Sakelaropoulos, T. (1991), "Institutional Transformation and Economic Development (18301922)", Athens,

Sideris, A. (1933), "The Agricultural Policy in Greece During the Period 1833-1933"

Soutsos, I. (1868), "Ploutologie", Athens

Stefanides, D. (1948), "Agricultural Policy", Athens

Tsoukalas, K. (1983), "Social Development and State: The Formation of Public Space in Greece", Athens

Vergopoulos, K. (1975), "Le Capitalisme Difforme et la Nouvelle Question Agraire", Maspero, Paris

Zografos, D. (1924), "History of the Greek Agriculture", Greek National Statistical Service, "Agricultural Statistics", Various Years 